\title{
THE IMPORTANCE OF TAX LITERACY IN TAX COMPLIANCE, SUGGESTIONS TO BE DEVELOPED IN THE CASE OF COUNTRY APPLICATIONS
}

\author{
Güneş ÇETIN GERGER ${ }^{1}$
}

\author{
Feride BAKAR TÜREGÜN²
}

Adnan GERÇEK ${ }^{3}$

\begin{abstract}
Taxes are the economic values that are received by the governments voluntary and the tax authorities under the enforcement according to the rules specified by the law. As tax is the most important source of income of the state, the approaches that strengthen tax awareness and increase tax compliance have become important for the revenue administrations. Tax literacy can be defined as having the ability to know and understand the tax-related issues, to follow them, to follow the developments, and to carry out their personal budget in the best way by considering the tax debts to be paid.

This study highlighted the importance of factors that determine the tax compliance in tax literacy and examined arrangements and projects related to tax literacy in the OECD countries and the United States and projects and researches related to tax literacy in Turkey are presented. In the study, it was concluded that the level of tax literacy in our country was not very good and suggestions were made about the activities that could be carried out to increase tax literacy.
\end{abstract}

Keywords: Tax literacy, tax compliance, tax awareness, tax psychology.

JEL Code: H2, K34, D91, H26

\section{Introduction}

Tax literacy is a new concept that founded on developed countries' applications bases.Tax literacy can be defined as the individual's understanding of tax laws related to tax liability, fulfilling her/his tax obligations and evaluating the possible tax risks independently in her/his financial environment (Cvrlj, 2015: 158). Therefore, there is a close relationship between tax literacy and tax compliance.

The factors affecting tax compliance are classified as moral, psychological, economic, demographic factors and factors related to tax management (Çetin Gerger, 2011: 9). There is a positive correlation between tax compliance and especially educational levels as a demographic factor. Tax awareness of taxpayers also develops with the increase in the level of education. Therefore, compliance behaviors of taxpayers increase (Otto et al., 1987: 304).

\footnotetext{
1 Assoc. Prof., Manisa Celal Bayar University, gunes.cetin@hotmail.com

2 Dr., Bursa Uludağ University, Faculty of Economic and Administrative Science, Public Finance Department, feridebakar@uludag.edu.tr

3 Prof. Dr., Bursa Uludağ University, Faculty of Economic and Administrative Science, Public Finance Department, agercek@uludag.edu.tr
} 
Today, developed revenue administrations in the world have changed the taxation approach from "despite the taxpayer" to "with the taxpayer" (Gerçek et al., 2015: 25). In this sense, revenue administrations have an important role in the development of tax literacy. In this study, the concept of tax literacy which is a basic sub-factor affecting tax compliance has been examined and the applications in developed countries and applications, as well as suggestions in our country, are discussed.

\section{Factors Affecting Tax Compliance And Tax Literacy}

\subsection{Factors Affecting Tax Compliance}

Taxpayers are generally not willing to pay taxes. For this reason, a field as the behavioral economy which affected psychological factors and examines tax compliance has been developed since 1970.This approach based on taxpayer's behavior and measures developed intrinsic motivation have adopted the principle of "trust is good, control is better". In this case, all the actors in the system determine the tax climate (Alm et al., 2012: 134).

The following figure shows the actors determining tax compliance. The tax climate has occurred as a result of the interactions between taxpayers and other taxpayers, government, tax authorities and accountants. The development of tax literacy ensures that the tax climate between these actors is positively affected.

Table 1. Actors and Determinants in the Formation of Tax Climate

\begin{tabular}{|c|c|c|}
\hline ACTORS & & DETERMINANTS \\
\hline Government & \multicolumn{2}{|c|}{ Governance and regulation, the image of taxpayers, tax law, the tax rate } \\
\hline Tax Authoriti & \multicolumn{2}{|c|}{ Images of government, tax accountants, taxpayers, audits, fines } \\
\hline Accountants & \multicolumn{2}{|c|}{ Images of government and tax authorities, taxpayers and their goals } \\
\hline Other Taxpayers & Taxpayers & $\begin{array}{l}\text { Images of government and tax authorities, attitudes, tax } \\
\text { morale, knowledge of tax law, norms (personal, social, societal), } \\
\text { justice (distributive, procedural, retributive) }\end{array}$ \\
\hline
\end{tabular}

Source: Alm et al., 2012: 136.

Nowadays, increasing tax compliance has become one of the important tasks of revenue administrations (Gerçek et al., 2015: 162).Successful revenue administrations have a management process that includes managerial approaches to optimize tax compliance such as risk-based verification programs, simple laws and procedures, taxpayer training and assistance (Russel, 2010: 2). In this respect, programs and sample practices that strengthen the communication between the taxpayer and the administration, including tax literacy, take place in all developed countries. 


\subsection{Importance and The Scope of Tax Literacy}

A person with a tax literate knows the basic concepts of taxation, has knowledge about the basic function of the tax system, follows the developments, knows the taxpayers' rights, can monitor how the taxes are used, has a positive attitude towards taxation, has a tax morality, knows the place of the tax in the personal budget, can fulfill own obligations related to tax.In this sense, tax literacy is completed by a behavioral dimension after passed through cognitive and emotional dimensions (Yılar \& Akdağ, 2017: 368).

Table 2. Cognitive Affective and Psychomotor Domains of Tax Literacy

\begin{tabular}{|c|c|}
\hline LEVELS & SCOPE \\
\hline Cognitive Level & $\begin{array}{l}\text { Being able to know the definition of a tax, } \\
\text { types of tax, } \\
\text { tax legislation, } \\
\text { tax rates, } \\
\text { important tax payment dates. }\end{array}$ \\
\hline Affective Level & $\begin{array}{l}\text { Being able to have tax perception, } \\
\text { belief in the necessity of tax payments, } \\
\text { positive tax attitude, } \\
\text { tax awareness, } \\
\text { tax ethics. }\end{array}$ \\
\hline Psychomotor Level & $\begin{array}{l}\text { Being able to fill the tax forms related to tax return } \\
\text { Being able to pay the tax debt by the relevant institutions or the internet }\end{array}$ \\
\hline
\end{tabular}

Source: Yılar \& Akdağ, 2017: 366.

Niemirowsaki, Baldwin \& Wearing (2003) research shows that there is a relationship between tax knowledge of taxpayers and tax compliance behaviors. In the survey of Eriksen \& Fallan (1996), it was determined that obtaining additional tax information increased tax compliance and reduced tax evasion. As citizens' knowledge of the tax increases, their confidence in government for its used correctly of taxes rises, while incomplete or misunderstanding results in distrust (Kirchler et al., 2008: 216).

Tax non-literate persons may unintentionally have a higher tax non-compliance (Chardon et al., 2016). The report "Building Tax Culture, Compliance and Citizenship"of OECD emphasized the transformation of state-citizen relations and the importance of cultural change in tax administration. Tax authorities once had a fear culture, but nowadays they recognize citizens not only as "liability holders" but also stakeholders (OECD, 2015: 17).Therefore, this change requires an understanding of tax perception and increasing tax awareness (Yalt, 2018: 65). Today, most countries which are the member of OECD recognize the limitations of traditional tax compliance techniques based on enforcement and emphasize on training programs for taxpayers to develop tax compliance and tax morality. 


\subsection{Regulations Regarding Tax Literacy in OECD Countries}

The OECD is a leader in measuring global financial literacy, including comprehensive measurement tools for adults and young people.In 2016, the second international financial literacy assessment report was published covering 30 countries (OECD, 2017: 13).Tax literacy is a sub-field of financial literacy. In order to get a general impression on tax literacy, financial literacy data are included in the research for $\mathrm{G} 20$ countries below. The following graph illustrates the data for this research.

\section{Graph 1. Financial Information, Behaviors, and Attitudes}

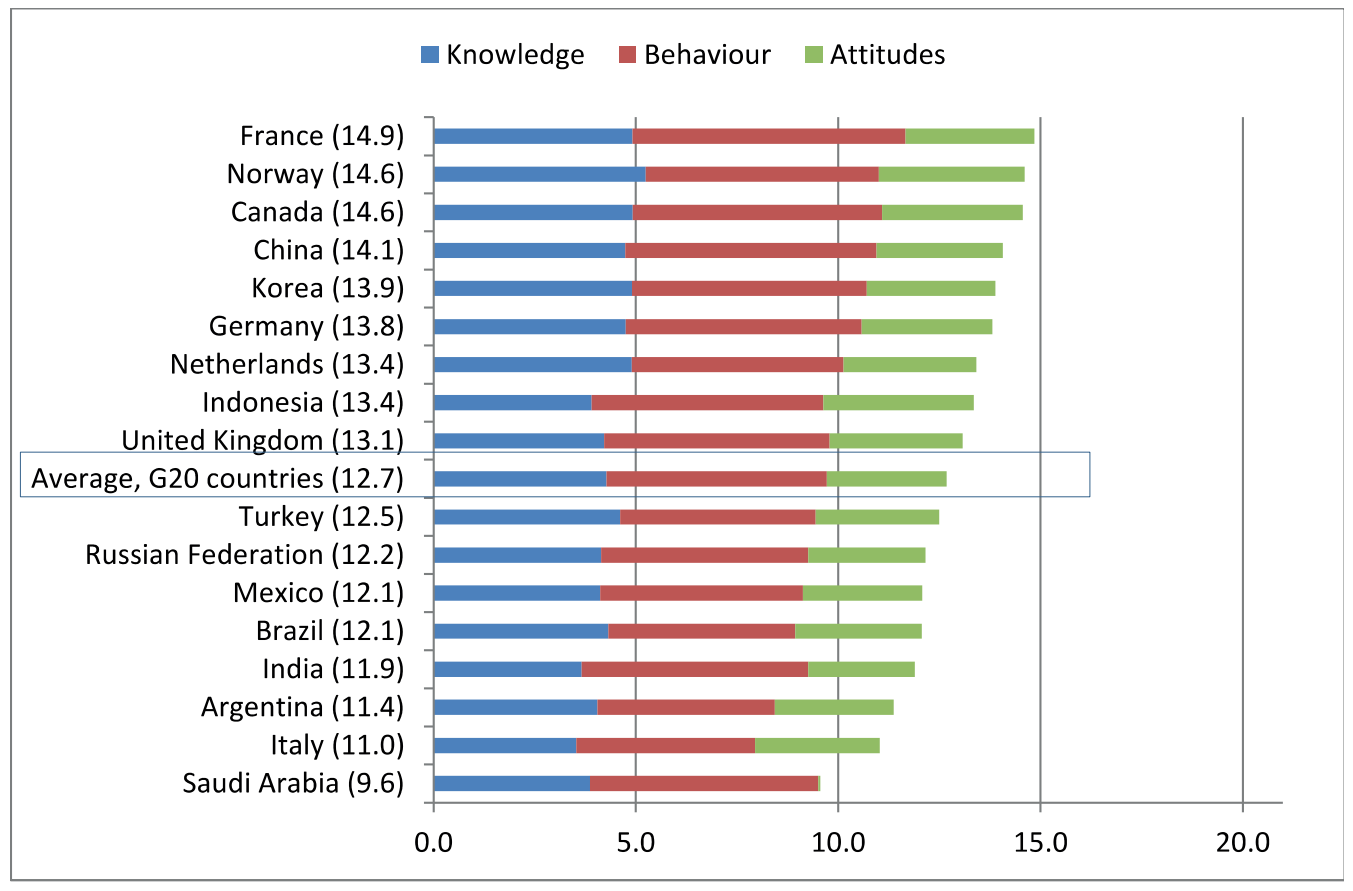

Source: OECD, 2017: 8.

This report shows that on average only $52 \%$ of adults reached the level of demonstration 6 of the 9 discussed attitudes in $\mathrm{G} 20$ countries. Although national surveys have been conducted in countries for tax literacy, only a report on financial literacy has been published by the OECD.In a report published by the OECD in 2015, tax literacy practices were mentioned in developing countries but did not include a score of tax literacy (OECD, 2015).Level of financial literacy in Turkey (12.5) is located just below the average of the G20 countries (12.7).

\subsection{Implementation of Tax Literacy Project in the USA}

The general purpose of the Tax Literacy Project carried out at Tulane University in the US is to inform public about taxation and to ensure that US citizens are informed about tax and tax policies and to enable citizens to make rational decisions as participants in future US tax policies.The project, which started in 2013, is still ongoing and supported by the IRS and the media.The project has three different concentration areas: 1 . Why we are taxed (the purpose of taxes; the link between tax and expenditure);2. Fairness of taxation (how the tax burden will be distributed, including the tax base and the rate structure); and 3. Basic concepts of taxation.The project is intended for people on all educational levels and all ages between 12 and 80 (https://taxjazz.com/). 


\section{Tax Literacy In Turkey}

There are a small number of studies to measure directly tax literacy in Turkey. In survey Akpınar \& Günay (2014), questions were asked about tax literacy and tax awareness for the taxpayers in Kahramanmaraş, and it was found that taxpayers know the \%65 name of the taxes in the tax system and \%42 in terms of the tax procedures and principles.Teyyare et al. (2018) questionnaires were applied to the students of Abant Izzet Baysal University, and tax literacy levels were found to be above the average level. However, tax knowledge of taxpayers in Turkey is accepted to be low.

In our country, there is no tax lesson at the primary, secondary and high school level, but some lessons contents include tax. The scope of some courses such as "Social Science" course, "Life Science" and "Human Rights" also includes tax liability (Turan \& Akdağ, 2017: 370-375).

On the other hand, in order to provide tax-related information to children of third, fourth and fifth-class, in 2007 "VerGiBilir - Training Programme for Developing Tax Awareness in Children" project protocol was signed between the Revenue Administration and the Ministry of National Education.Teachers who took part in the project were given micro tax teaching practice courses in 2009 and the project was completed in 2012.In this context, various books and brochures were prepared and especially the website was established together with the games (GiB, 20082014 Annual Reports).

\section{Suggestions For Turkey To Improve Tax Literacy}

The development of academic literature is required in Turkey to increase tax literacy. However, if these studies are carried out at an empirical level, it will be useful.There should be practices from Revenue Administration which have a widespread effect and which can contribute to voluntary compliance. In the lesson of elementary education should include tax concepts in social studies.

While it is important to increase the tax literacy from primary education, it is necessary for families to inform the children at all stages in order to make positive opinion in tax matters and to spread this to the society. This situation, which is necessary for the development of conceptual infrastructure, should be given to the people between the ages of 12 and 80 as in the USA appropriate with the philosophy of lifelong learning.

Tax literacy training can be realized at a low cost with the contributions of law and finance students. These applications can also be considered an intern training. It can be an application that will improve the awareness of citizenship as well as increase tax literacy. Compliance levels of taxpayers can be determined by questionnaires before and after these training and a strategy can be developed by the Revenue Administration. In addition, tax literacy training within the scope of digital literacy can be developed in accordance with Industry 4.0.

In order to increase tax literacy, long-term activities will be designed and tax compliance will be increased, thus this will reduce the need to allocate resources to prevent tax evasion and informality. For this reason, it is useful to implement the following recommendations for the development of tax literacy:

- Academic studies should be increased in order to reveal the importance of tax literacy.

- Tax training should be implemented in many areas, not just children, but by selecting specific target groups.

- Taxpayers should be informed about tax guides and brochures and their usage should be increased. 


\section{Conclusion}

Today, global realities are changing rapidly, nation-states' protection of tax revenues is only possible by optimizing tax compliance. The main actor in tax compliance is taxpayers. Education is the most important element that can ensure the compliance of the taxpayer. Many activities to learn many concepts include citizenship awareness, tax awareness, perception of revenue administration, tax perception, tax morality, tax knowledge should be organized at the academic and administrative level to increase and improve tax literacy. In developed countries, academic activities related to tax literacy are higher. Because studies show a positive correlation between tax literacy and tax compliance.

Tax literacy-related activities in Turkey is seen as a more in theadministrative level. For this reason, increasing the academic studies to create tax awareness and increase tax literacy and their implementation in cooperation with administrative works will positively affect tax compliance in our country.

\section{References}

Alm, J., Kirchler, E. \& Muehlbacher, S. (2012). “Combining Psychology and Economics in the Analysis of Compliance: From Enforcement to Cooperation", Economic Analysis and Policy, Elsevier, vol. 42(2), pp. 133-152.

Chang Otto, H., Nichols Donald, R. \& Schultz Joseph, J. (1987). "Taxpayer Attitudes Toward Tax Audit Risk", Journal of Economic Psychology, 8(3), pp. 299-309.

Chardon, T., Freudenberg, B. \& Brimble, M. (2016). "Tax Literacy in Australia: Not Knowing Your Deduction From Your Offset", Australian Tax Forum, vol 31(2), pp. 321-362. https://search. informit.com.au/documentSummary; dn=167713818520655; res=IELBUS, (15.02.2019).

Cvrlje, D. (2015). "Tax Literacy as an Instrument of Combating and Overcoming Tax System Complexity, Low Tax Morale and Tax non-Compliance", The Macrotheme Review, 4(3), pp. 156-167.

Çetin Gerger, G. (2011). Mükellef Hakları ve Vergiye Gönüllü Uyum, İstanbul, Legal Kitabevi.

Eriksen, K. \& Fallan, L. (1996). "Tax Knowledge and Attitudes Towards Taxation: A Report on A Quasi-Experiment", Journal of Economic Psychology, 17(3), pp. 387-402.

Gerçek, A., Çetin Gerger, G., Taşkın, Ç., Bakar, F. \& Güzel, S. (2015). Mükellef Hakları: Türkiye Perspektifi ve Geliştirilmesi, Ankara, Seçkin Yayıncılık.

GiB. 2008-2014 Faaliyet Raporları, http://www.gib.gov.tr/kurumsal/stratejik-yonetim/ faaliyetraporlari, (20.02.2018).

Kirchler, E., Hoelzl, E. \& Wahl, I. (2008). “Enforced Versus Voluntary Tax Compliance: The 'Slippery Slope' Framework", Journal of Economic Psychology, 29, pp. 210-225.

Kornhauser, M. E. (2019). TaxJazz: The Tax Literacy Project, https://taxjazz.com/, (18.02.2019).

Niemirowsaki, P., Baldwin, S. \& Wearing, A. J. (2003). "Tax Related Behaviours, Beliefs, Attitudes and Values and Taxpayer Compliance in Australia", Journal of Australian Taxation, 6(1), pp. 132-165. 
OECD. (2017). G20/OECD INFE Report on Adult Financial Literacy in G20 Countries, http://www. oecd.org/daf/fin/financial-education/G20-OECD-INFE-report-adult-financial-literacy-inG20-countries.pdf, (16.02.2019)

OECD. (2015). The International and Ibero-American Foundation for Administration and Public Policies (FIIAPP), Building Tax Culture, Compliance and Citizenship: A Global Source Book on Taxpayer Education, OECD Publishing, Paris.

Russell, B. (2010). Revenue Administration: Developing a Taxpayer Compliance Program, Technical Notes and Manuals (Washington DC: IMF), https://www.imf.org/external/pubs/ $\mathrm{ft} / \mathrm{tnm} / 2010 / \mathrm{tnm} 1017 . \mathrm{pdf}$ (14.02.2019).

Teyyare, E., Ayyıldız, B., Dirican, H., Zıvalı, B.S. \& Renkli, B. (2018). “iktisadi ve Mali Okuryazarlık Üzerine Bir Araşttrma: Abant İzzet Baysal Üniversitesi İktisadi ve İdari Bilimler Fakültesi Örneği", Ekonomik ve Sosyal Araşttrmalar Dergisi, 14(1), pp. 99-120.

Yalt, B. (2018). Cross-Border Tax Challenges In The 21st Century-21. Yüzyılda Sınır Ötesi Vergi Sorunları, İstanbul, Onikilevha Yayıncılık.

Yardımcıoğlu, M., Akpınar, Y. \& Günay, Y. (2014). “Vergi Okuryazarlığı ve Vergisel Farkındalık: Kahramanmaraş Araştırması", Kahramanmaraş Sütçü Imam Üniversitesi IiBF Dergisi, 4(2), pp. 95-119.

Yılar, M. B. \& Akdağ, H. (2017). "Sosyal Bilgiler Öğretiminde Vergi Okuryazarlığı", Sosyal Bilgiler Eğitiminde Yeni Yaklaşımlar III, Ed.: Turan R. \& Akdağ H., Ankara, Pegem Akademi. 